\title{
Self-assessed and self-reported lifestyle of people at risk of cardiovascular diseases
}

\author{
Eeva-Leena Ylimäki ${ }^{1}$, Outi I. Kanste ${ }^{2}$, Hanna P. Heikkinen ${ }^{3}$, Risto Bloigu ${ }^{4}$, Helvi A. Kyngäs ${ }^{1}$ \\ 1. Institute of Health Sciences, University of Oulu, Oulu, Finland. 2. National Institute for Health and Welfare, Helsinki, \\ Finland. 3. Department of Mathematical Sciences, University of Oulu, Oulu, Finland. 4. Medical Informatics Group, \\ University of Oulu, Oulu, Finland.
}

Correspondence: Eeva-Leena Ylimäki. Address: Institute of Health Sciences, University of Oulu, Oulu, Finland.

Received: January 22, 2014

Accepted: June 3, $2014 \quad$ Online Published: June 23, 2014

DOI : $10.5430 /$ jnep.v4n9p13

URL: http://dx.doi.org/10.5430/jnep.v4n9p13

\begin{abstract}
Background: Lifestyle affects the risk of suffering from cardiovascular diseases. Lifestyle and health behaviour are most commonly studied by using self-assessment and self-reporting as a research method. The purpose of this study was to illustrate how asymptomatic people with a diagnosed risk of cardiovascular diseases assess and report their current lifestyle. In particular, the study evaluated how the participants' self-assessed and self-reported lifestyles correlated with health parameters that were measured such as blood pressure, cholesterol level, body mass index (BMI) and waist circumference.

Methods: The study material was obtained from a cardiovascular health project in Lapland, Finland, which aimed at identifying 40-year-old individuals at risk of cardiovascular disease. Screening consisted of blood tests (total level of cholesterol, HDL, LDL, plasma glucose) and health parameter measurements (blood pressure, BMI and waist circumference). All participants filled in a diabetes risk test, lifestyle questionnaire and dietary and physical activity diaries. Data analyses included statistical analyses, cross-tabulation, Fisher's Exact test (FET) and Micro-Nutrica Nutritional Analysis Program.

Results: $37.3 \%$ of the participants assessed themselves to be obese and $54.9 \%$ thought themselves to be slightly overweight although the calculated average BMI $\left(30.7 \pm 5.4 \mathrm{~kg} / \mathrm{m}^{2}\right)$ showed clearly that they were overweight. Over half of the participants $(54.7 \%)$ assessed themselves as having the recommended amount of everyday physical activity per week but the physical activity diaries showed that the real amount was significantly less and inadequate in terms of their health. Inadequate physical activity was connected to obesity. As well as the use of hard fat, vegetable and fibre intake was too low which may have contributed to the elevated total cholesterol and LDL levels in the blood tests. This research showed both over- and under-reporting. Particularly, differences in reporting were observed between overweight and normal weight participants in addition to those whose blood test results exceeded recommended level compared with those having results within the normal range. Over half of the participants assessed their health to be either good or at least quite good. Some correlation between the self-assessed lifestyle and health parameters measured were found.
\end{abstract}

Conclusions: The strengths of this study were the multifaceted data collection approach, which provided a versatile view of studying lifestyle, and the special nature of engaging voluntary participants to screenings and the reporting process. Participants' own assessments regarding their lifestyle were not fully in line with either the reported lifestyle or health 
parameter measurement results. This study clearly showed that physical activity and food diaries together with health parameter measurements provide additional information about self-assessed lifestyle.

\section{Key words}

Self-assessment, Self-reporting, Cardiovascular health, Lifestyle

\section{Introduction}

A healthier way of living plays a significant role in preventing cardiovascular diseases, the most common reason for death worldwide. WHO has prepared action plans and strategies to promote a healthier lifestyle that underline nutrition and physical activity as the essence of achieving this goal globally ${ }^{[1]}$. Also, the European Union has devised an action plan for healthy nutrition and physical activity, as well as a strategy to improve national public health ${ }^{[2,3]}$. In Finland, the Ministry of Social Affairs and Health has devised a strategy aimed at promoting healthier lifestyles ${ }^{[4]}$.

People at risk of cardiovascular diseases need to change their lifestyle and live in a healthier way. Consequently, one can positively influence his/her cardiovascular health by implementing a healthy lifestyle which consists of regular physical activity, healthy eating, moderate alcohol consumption and no smoking ${ }^{[5,6]}$.

Lifestyle and health behaviour are most commonly studied by using self-assessment and self-reporting as a research method. There are different types of questionnaires and diaries which study areas such as tobacco and alcohol use, eating habits, weight and physical activity ${ }^{[7,8]}$. However, studying lifestyle is challenging with regards to the validity and generalisation of the results. Indeed, self-assessment is always subjective and prone to error through possible over-reporting and under-reporting ${ }^{[9-11]}$. In addition, cognitive factors such as recall and understanding affect selfassessment $^{[7,10]}$.

\subsection{Purpose of the study}

A large cardiovascular health project took place in Lapland, Finland, which aimed at identifying, using a screening process, those individuals of a specific age at risk of cardiovascular disease. In Finland, basic health care is developed through such projects, which aim to introduce new and more advanced health practices for special target groups, for example to treat special chronic diseases. In particular, these projects focus on preventative care in order to improve overall health.

The purpose of this study was to illustrate how asymptomatic 40-year-old people, diagnosed with a risk of cardiovascular diseases as a result from the screening, assess and report their current lifestyle. The research questions were:

- What is the participants' current lifestyle and cardiovascular health?

- How do the participants assess their current health and lifestyle?

- How are the participants' self-assessed and self-reported lifestyle parameters in line with the health parameters measured?

\subsection{Frame of reference}

In this study, self-assessment refers to a situation where a participant chooses the most suitable answer from options given in a questionnaire according to his/her own feelings. Consequently, self-assessment always involves emotions which may affect the results.

Self-reporting in this study, on the other hand, refers to participants' records of physical activity (actual exercise as times or minutes per day/week) and diet (actual food intake as units or decilitre per portion) after the event. 


\section{Methods}

\subsection{Setting}

The study population consisted of 53 participants with an identified risk of cardiovascular disease. A large cardiovascular health project took place in Lapland, Finland, which aimed at identifying, using a screening process, those individuals of a specific age at risk of cardiovascular disease. This study, in part, used the project's study setup and material.

The project's study population was formed from people who turned 40 years during the project. 21 municipalities were invited to take part in the project and 8 of them decided to participate. The total number of possible participants was 571; of these, 286 (51\%) participated. 98 (34\%) participants were identified as being at risk of cardiovascular disease and these people were then invited to take part in an intervention (the main focus in the project). 76 (78\%) volunteered for the intervention and they were provided with the opportunity to take part in this study. Consequently, 53 volunteered to participate (see Figure 1).

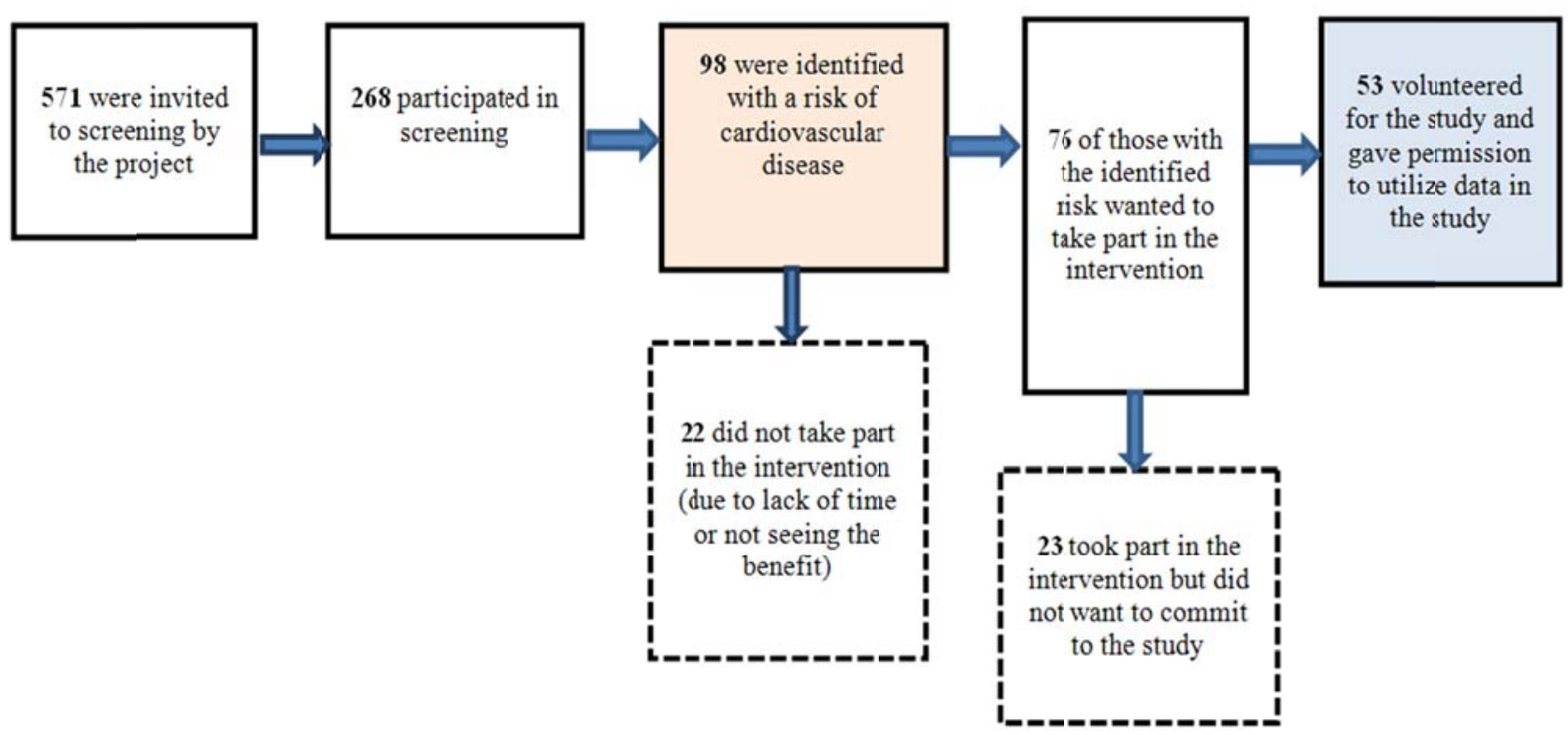

Figure 1. Forming the study population

\subsection{Data collection}

\subsubsection{Screening process}

The screening process was managed by health care professionals. First, participants were invited by local health care centres to undertake a blood test which included measurements of the level of cholesterol (total, high density lipoprotein, low density lipoprotein) and plasma glucose. Then each participant attended a personal screening meeting where additional health parameters (blood pressure, BMI and waist circumference) were measured. In addition, all participants filled in a diabetes risk test and a lifestyle questionnaire during this meeting and the results from blood tests, measurements and questionnaires were also discussed (see Table 1).

At the end of the meeting, participants received special instructions on how to keep a diary of physical activity and food intake. 
Table 1. Study material

\begin{tabular}{ll}
\hline Indicator & Contents \\
\hline Blood test & total cholesterol, HDL, LDL, plasma glucose \\
Health parameters & blood pressure, weight, height, waist circumference, BMI \\
& $\begin{array}{l}\text { age, blood pressure medication, glucose levels, BMI, waist circumference, daily consumption of } \\
\text { The Diabetes risk test }\end{array}$ \\
vifestyle questionnaires & diet, physical activity, alcohol consumption, smoking, changes in weight and health \\
Physical activity & everyday physical activity, physical fitness \\
Diet records & food and drink intake, meal times and circumstances \\
\hline
\end{tabular}

\subsubsection{Self-assessment}

To study their current lifestyles, participants filled in a specially designed lifestyle questionnaire. The lifestyle questionnaire explored the participants' own assessment of certain lifestyle parameters such as the time spent weekly on everyday and fitness-related physical activities, physical condition, importance of exercise regarding well-being, meal times, the quality and quantity of food, perception of personal weight and changes in weight. Alcohol and cigarette consumption (previous and current) were also assessed.

The risk for type 2 diabetes was assessed using a separate diabetes risk test ${ }^{[12,13]}$. The test uses participant's age, blood pressure medication, waist circumference, BMI, heredity, plasma glucose, daily vegetable use and amount of physical activity. The risk is identified on a 5-level scale.

\subsubsection{Self-reporting}

Participants kept a record of physical activity for four weeks (28 days). In this study, everyday physical activity referred to exercise a person does whilst carrying out, for example, household work, gardening and active commuting. The criteria for everyday physical activity were that it lasted for a minimum of 30 minutes per day and that it was moderately vigorous.

In order to count as physical fitness, on the other hand, the criteria were that exercise was continuous, lasted a minimum of 20 minutes, and left the person out of breath and perspiring. In addition to the amount of exercise, the type of physical fitness was also reported in the diary.

The food diary was kept for four consecutive days, one of which had to be during the weekend. The diary records consisted of mealtime, place, circumstances and all food consumed (pieces and size of portion).

\subsection{Data analysis}

SPSS for Windows 19.0 was used for the statistical analysis. Common guidelines for BMI, cardiovascular health parameters and waist circumference were used in the categorization of variables. The lifestyle variables were analysed using cross-tabulation and the association between variables was examined using the Chi-square test as well as Fisher's Exact test (FET). The threshold for statistical significance was set at FET $p$-value .05. Significance values between 0.05 and 0.1 were treated as suggestive.

Everyday physical activity and physical fitness were analysed by using the physical activity diaries. Physical fitness activities were categorized into aerobic, muscular fitness and mobility exercise. The analysis calculated the average and median of days and time spent on everyday physical activity and physical fitness. The median was used in the results since the distributions were not normal.

There were 39 physical activity diaries returned in which the amount of everyday physical activity and/or physical fitness had been distinctly documented. There were also a total of 39 food diaries returned. They were forwarded to a dietician 
(student majoring in Clinical nutrition at the University of Eastern Finland, faculty of Health Sciences) for analysis. They were analysed using the Micro-Nutrica Nutritional Analysis Program.

\section{Results}

All study participants (men 57\%, women 43\%) had been identified with at least one risk factor for cardiovascular diseases before entering the study. Over half of the participants had a low education level. $76 \%$ of the participants had physically-demanding jobs. Participant characteristics are shown in Table 2.

\subsection{Obesity}

According to this study, $37.3 \%$ of the participants assessed themselves to be obese and over half of them thought themselves slightly overweight (see Table 3). The difference in self-assessments between men and women was statistically significant (FET $p$-value .047). $72.7 \%$ of men assessed themselves to be only slightly overweight and $27.3 \%$ to be obese. For women, the figures were $41.2 \%$ and $44.8 \%$ respectively.

Table 2. Distribution of socio-demographic characteristics $(n=53)$

\begin{tabular}{|c|c|c|}
\hline Characteristics & $\mathbf{n}$ & $\%$ \\
\hline \multicolumn{3}{|l|}{ Marital status } \\
\hline Married/cohabiting & 46 & 87 \\
\hline Other & 7 & 13 \\
\hline \multicolumn{3}{|l|}{ Education level } \\
\hline Low & 27 & 51 \\
\hline Medium & 17 & 32 \\
\hline High & 9 & 17.0 \\
\hline \multicolumn{3}{|l|}{ Employment status } \\
\hline Manual paid work & 16 & 31 \\
\hline Non-manual paid work & 24 & 46 \\
\hline Unemployed & 13 & 23 \\
\hline \multicolumn{3}{|l|}{ Work situation at the moment } \\
\hline At work & 40 & 76 \\
\hline Does not work & 13 & 25 \\
\hline \multicolumn{3}{|l|}{ Medical consultation during the last year } \\
\hline 0 & 18 & 35 \\
\hline $1-2$ & 19 & 37 \\
\hline$>3$ & 14 & 27 \\
\hline \multicolumn{3}{|c|}{ During the past year diagnosed with a medical condition and / or manages condition } \\
\hline Cardiovascular disease and associated risks & 14 & 29 \\
\hline Other conditions(for example cancer, spinal injury) & 8 & 17 \\
\hline No illnesses & 26 & 54 \\
\hline \multicolumn{3}{|l|}{ Number of children } \\
\hline 0 & 12 & 23 \\
\hline $1-2$ & 26 & 49 \\
\hline$>3$ & 15 & 28 \\
\hline
\end{tabular}

However, according to measurements, the total BMI average was 30.4 (recommendation $<24.9$ ). $61 \%$ of men and $47 \%$ of women had a BMI greater than $30.69 .6 \%$ of men had a waist circumference larger than $102 \mathrm{~cm}$ (recommendation $<90$ $\mathrm{cm}$ ), while $63.3 \%$ of women had a waist circumference that exceeded $88 \mathrm{~cm}$ (recommendation $<80 \mathrm{~cm}$ ). 
According to the participants' own assessment, $42.6 \%$ believed that they had gained weight during the previous year. Women (58.6\%) particularly felt that they had gained weight whereas only $16.7 \%$ of men felt the same. The difference was statistically significant (FET $p=.011$ ).

\subsection{Quality of diet}

Over half of the participants (64.2\%) assessed that they had a healthy or quite healthy diet. However, at the same time, $69.8 \%$ assessed that they ate less than $500 \mathrm{~g}$ per day of vegetables and only $13.2 \%$ assessed that they included approximately $500 \mathrm{~g}$ of vegetables in their diet per day ( $17 \%$ could not say).

Over half of the participants assessed that they used soft fat on bread (54.7\%) and in cooking (51.9\%). 26.4\% said they used bread which had a fibre content of more than $10 \mathrm{~g} / 100 \mathrm{~g}$ of bread (see Table 3). On the other hand, $41.5 \%$ of all the participants were not able to tell how much fibre the bread used daily contained, especially men $(60.9 \%) .62 .3 \%$ of the participants claimed to read through product descriptions on grocery packaging (see Table 3).

According to the food diaries, the total energy intake on average was $1692 \mathrm{kcal}$. The amount of saturated fats used was 13 $\mathrm{E} \%$, the amount of monounsaturated fats $11 \mathrm{E} \%$, and the amount of polyunsaturated fats $5.5 \mathrm{E} \%$. Average vegetable intake was $261 \mathrm{~g}$ /day and fibre intake $19.5 \mathrm{~g} /$ day. Carbohydrate intake per day was below the recommended level. Salt intake was $3941 \mathrm{mg} /$ day (see Table 4).

The participants' average total cholesterol level and LDL cholesterol were higher than recommended. The risk of type 2 diabetes was increased to some extent (see Table 5).

\subsection{Alcohol and tobacco use}

Over half of the participants assessed that they consumed alcohol once a month, or less than once a month and, overall, women assessed that they consumed alcohol less than men (FET p-value .012). 40.0\% assessed that the strength of alcohol they consumed was, by volume, $2.9 \%-4 \%$. Single dose of alcohol was smaller with women than with men (FET $p$-value .044) but women consumed stronger alcohol (alcohol by volume $>4.7 \%$ ) than men (FET $p$-value .037).

$37.7 \%$ had never smoked and $62.3 \%$ had smoked at some point. At the time of the study, $18.9 \%$ smoked every day, $9.4 \%$ smoked occasionally and $71.7 \%$ did not smoke at all.

\subsection{Physical activity}

Of all the participants, $93.3 \%$ thought that regular exercise had an effect on their well-being. $57.7 \%$ assessed their health to be at least quite good; $56.7 \%$ assessed their physical condition to be satisfactory (see Table 3).

Over half of the participants (54.7\%) assessed that they took a total of 3-4 hours of everyday physical activity per week when, on the other hand, $26.4 \%$ could not evaluate whether they achieved the recommended level of everyday physical activity. $32.7 \%$ of the participants believed that they achieved the minimum physical fitness recommendation (2-3 hours/week for at least 20-60 minutes) but $11.5 \%$ could not evaluate whether they achieved the recommended level of physical fitness (see Table 3).

Based on physical activity diaries, however, the median for everyday physical activity was 12 days/4 weeks, on which at least 30 minutes of everyday physical activity was documented. Participants reported doing physical fitness exercise on 9 days / 4 weeks, with the average total time taken being 7 hours. Physical fitness exercise was aerobic and included walking, Nordic walking, running, cycling and skiing. Muscular strengthening and balance training were documented in 12 diaries, with the median time spent being $2.5 \mathrm{~h} / 4$ weeks (see Table 6). 
Table 3. Participants' self -assessed lifestyle $(\mathrm{n}=53)$

\begin{tabular}{|c|c|}
\hline Variable & $\%$ \\
\hline \multicolumn{2}{|l|}{ Opinion of weight } \\
\hline Slightly overweight & 54.9 \\
\hline Obese & 37.3 \\
\hline \multicolumn{2}{|l|}{ Changes in weight } \\
\hline has increased in the last year & 42.6 \\
\hline has stayed the same in the last year & 38.3 \\
\hline has decreased in the last year & 19.1 \\
\hline \multicolumn{2}{|l|}{ Health } \\
\hline very or quite good & 57.7 \\
\hline average level & 38.5 \\
\hline poor & 3.8 \\
\hline \multicolumn{2}{|l|}{ Exercise } \\
\hline $3-4$ hours of everyday activities a week & 54.7 \\
\hline I cannot say & 26.4 \\
\hline $2-3$ hours of fitness activities a week for $20-60 \mathrm{~min}$ & 32.7 \\
\hline Fitness activities below recommendation & 55.8 \\
\hline I cannot say & 11.5 \\
\hline Satisfactory physical condition & 56.7 \\
\hline Exercise affects wellbeing & 93.3 \\
\hline \multicolumn{2}{|l|}{ Diet } \\
\hline $1-2$ meals and snacks a day & 41.5 \\
\hline $3-4$ meals and snacks a day & 45.3 \\
\hline Diet affects wellbeing & 84.9 \\
\hline I cannot say & 15.1 \\
\hline Eats a fairly healthy diet, or a quite healthy diet & 64.2 \\
\hline Eats $\geq 500$ grams of vegetables a day & 13.2 \\
\hline Eats $<500$ grams of vegetables a day & 69.8 \\
\hline I cannot say & 17.0 \\
\hline Uses light and soft fat products on bread & 54.7 \\
\hline Uses soft fats when preparing food & 51.9 \\
\hline Mainly uses low-fat cheese & 34.0 \\
\hline Mainly uses low fat cold-cuts & 56.6 \\
\hline Uses bread with fibre content above $10 \mathrm{~g} / 100 \mathrm{~g}$ & 26.4 \\
\hline Uses bread with fibre content above $6 \mathrm{~g} / 100 \mathrm{~g}$ & 22.6 \\
\hline I cannot say & 41.5 \\
\hline Eats sugary and fatty snacks daily & 43.3 \\
\hline Uses the plate model when putting together a meal & 24.5 \\
\hline Reads through the descriptions on grocery packages & 62.3 \\
\hline \multicolumn{2}{|l|}{ Alcohol usage } \\
\hline once a month or less often & 51.9 \\
\hline $2-4$ times a month & 30.8 \\
\hline \multicolumn{2}{|l|}{ Amount consumed when drinking } \\
\hline $0-1$ units & 38.8 \\
\hline $3-4$ units & 28.6 \\
\hline \multicolumn{2}{|l|}{ Volume of alcohol per drink } \\
\hline $2.9-4.7 \%$ & 40.0 \\
\hline$>4.4 \%$ & 28.0 \\
\hline
\end{tabular}


Table 4. Diet according to diary records $(n=53)$

\begin{tabular}{|c|c|c|c|}
\hline Variable & Mean & Median & SD \\
\hline Total energy (kcal) & 1692 & 1669 & 486 \\
\hline Total fats (E\%) & 35 & 34 & 7.01 \\
\hline Saturated fats $(\mathrm{E} \%)$ & 13 & 13 & 3.58 \\
\hline Monounsaturated fats $(\mathrm{E} \%)$ & 11 & 11 & 3.03 \\
\hline Polyunsaturated (E\%) & 5.5 & 6 & 1.3 \\
\hline Protein (E\%) & 19 & 19.5 & 2.9 \\
\hline Carbohydrates (E\%) & 44 & 44 & 8.09 \\
\hline Fibre (g) & 19.5 & 19,6 & 6.9 \\
\hline Cholesterol (mg) & 242 & 230 & 107.3 \\
\hline Vitamin C (mg) & 71 & 72 & 36.6 \\
\hline Vitamin D (mg) & 6.1 & 5.6 & 3.6 \\
\hline Folic acid ( $\mu \mathrm{g})$ & 227 & 214 & 64.8 \\
\hline Sodium (mg) & 3941 & 2690 & 941 \\
\hline Vegetables (g) & 261 & 265.6 & 126.5 \\
\hline Fruit (g) & 106 & 102 & 70.75 \\
\hline Berries (g) & 19 & 0 & 31.8 \\
\hline Root vegetables (g) & 25 & 17 & 31 \\
\hline Green vegetables (g) & 97 & 88 & 61.53 \\
\hline Nuts and pulses (g) & 2 & 0.5 & 3.84 \\
\hline Potatoes (g) & 87 & 78.5 & 56.2 \\
\hline
\end{tabular}

Table 5. Cardiovascular health $(\mathrm{n}=53)$

\begin{tabular}{|c|c|c|c|}
\hline \multicolumn{4}{|c|}{ Variable } \\
\hline & Mean & Median & SD \\
\hline Systolic blood pressure (mmHg) & 132 & 129 & 16.5 \\
\hline Diastolic blood pressure (mmHg) & 87 & 86 & 12.6 \\
\hline Total cholesterol (mmol/1) & 5.2 & 5.2 & 1.0 \\
\hline HDL-cholesterol (mmol/l) & 1.32 & 1.28 & 0.31 \\
\hline LDL-cholesterol (mmol/l) & 3.26 & 3.26 & 0.66 \\
\hline Diabetes Risk Score* & 9 & 10 & 4.3 \\
\hline Glucose (mmol/1) & 5.35 & 5.35 & 0.48 \\
\hline BMI & 30.4 & 30.4 & 5.4 \\
\hline \multicolumn{4}{|l|}{ Waist circumference } \\
\hline Men & 106 & 105 & 11.3 \\
\hline Women & 95 & 92 & 14.6 \\
\hline
\end{tabular}

* risk of type 2 diabetes is $4 / 100$

Table 6. Everyday physical activity and physical fitness as exercise days and time spent over 28 days

\begin{tabular}{lllllll}
\hline & \multicolumn{2}{l}{ Day } & \multicolumn{3}{c}{ Time in hours } \\
\cline { 2 - 7 } & Mean & Median & SD & Mean & Median & SD \\
\hline Everyday physical activity & 12 & 12 & 8.04 &.. &.. &.. \\
Physical fitness & 9 & 8 & 5.6 & 7 & 5 & 6 \\
\hline
\end{tabular}




\subsection{Correlation between self-assessment and measurements}

Some correlation between the self-assessed lifestyle and the health parameters measured was found (see Table 7). Women whose waist circumference was at the recommended level assessed themselves to eat bread which contained a high amount of fibre (FET $p$-value .026). Those participants whose LDL cholesterol level was within the normal range assessed themselves to be obese while, on the other hand, those whose LDL cholesterol level exceeded the recommended level assessed themselves to be only slightly obese (FET $p$-value .009). Those participants whose HDL cholesterol level was below the recommended level but who assessed that they experienced everyday physical activity as recommended (FET $p$-value .034) assessed their health to be average (FET $p$-value .053).

Participants with a total cholesterol level exceeding the recommended level assessed themselves slightly overweight while, on the other hand, those whose cholesterol level was as recommended assessed themselves to be obese. In addition, participants with normal cardiovascular health parameters underestimated the healthiness of their lifestyle. Contrastingly, those participants whose cardiovascular health parameter measurement results exceeded recommendations overrated the healthiness of their lifestyle.

\section{Discussion}

In this study, it was shown how people with a diagnosed risk of cardiovascular diseases assess and report their current lifestyle. The study reveals interesting observations about participants' self-assessment and self-reporting. Table 8 shows the main findings of how lifestyle relates to self-assessment, self-reporting and the health parameters measured.

Participants did not consider themselves to be obese although measurements showed otherwise. Abdominal obesity was clearly evident. Women were found to be more critical about the perception of their weight than men. Being overweight indicates a lifestyle where there is little physical activity, a good deal of sitting down and a diet that does not adhere to recommendations ${ }^{[14-17]}$. The more obese a person is, the more likely that person is to be at a risk of cardiovascular diseases ${ }^{[18]}$.

Table 7. Self-assessed lifestyle parameters, health parameter measurements and their relationship

\begin{tabular}{|c|c|c|c|c|c|c|c|c|c|c|c|c|c|c|}
\hline & $\%$ & $\begin{array}{l}\text { Slightly } \\
\text { over- } \\
\text { weight }\end{array}$ & $\begin{array}{l}\text { Ob- } \\
\text { ese }\end{array}$ & $\begin{array}{l}\text { Health } \\
\text { very or } \\
\text { quite } \\
\text { good }\end{array}$ & $\begin{array}{l}\text { Health } \\
\text { averag } \\
\text { e level }\end{array}$ & $\begin{array}{l}3-4 \\
\text { hours of } \\
\text { everyday } \\
\text { activities } \\
\text { a week }\end{array}$ & $\begin{array}{l}\text { I } \\
\text { cannot } \\
\text { say }\end{array}$ & $\begin{array}{l}2-3 \text { hours of } \\
\text { fitness } \\
\text { activities a } \\
\text { week for } \\
20-60 \mathrm{~min}\end{array}$ & $\begin{array}{l}\text { I can } \\
\text { not } \\
\text { say }\end{array}$ & $\begin{array}{l}\text { Eats } 500 \\
\text { grams of } \\
\text { vegetable } \\
\mathrm{s} \text { a day }\end{array}$ & $\begin{array}{l}\text { I can } \\
\text { not } \\
\text { say }\end{array}$ & $\begin{array}{l}\text { Uses } \\
\text { light } \\
\text { and } \\
\text { soft fat } \\
\text { produ } \\
\text { cts on } \\
\text { bread }\end{array}$ & $\begin{array}{l}\text { Uses } \\
\text { bread } \\
\text { contain- } \\
\text { ing } \\
\text { fibre > } \\
10 \mathrm{~g} / 100 \mathrm{~g}\end{array}$ & $\begin{array}{l}\text { I } \\
\text { can } \\
\text { not } \\
\text { say }\end{array}$ \\
\hline $\begin{array}{l}\text { Systolic blood } \\
\text { pressure/mmHg }\end{array}$ & \multicolumn{14}{|c|}{$p=.022 *$} \\
\hline$<129$ & 50 & 41.7 & 45.8 & 70.8 & 25.0 & 57.7 & 23.1 & 34.6 & 11.5 & 11.5 & 19.2 & 50.0 & 26.9 & 46.2 \\
\hline $130-139$ & 23 & 75.0 & 25.0 & 50.0 & 41.7 & 41.7 & 41.7 & 41.7 & 16.7 & 33.3 & 16.7 & 50.0 & 25.0 & 8.3 \\
\hline$>140$ & 27 & 66.7 & 33.3 & 49.9 & 57.1 & 61.5 & 23.1 & 25.0 & 8.3 & 0.0 & 15.4 & 61.5 & 23.1 & 69.2 \\
\hline Cholesterol & \multicolumn{14}{|c|}{$p=.091 *$} \\
\hline$<5 \mathrm{mmol} / 1$ & 42 & 36.8 & 52.6 & 70.7 & 30.0 & 52.4 & 23.8 & 33.3 & 9.5 & 14.3 & 14.3 & 54.1 & 33.3 & 38.1 \\
\hline$>5 \mathrm{mmol} / \mathrm{l}$ & 58 & 67.9 & 28.6 & 48.3 & 44.8 & 56.7 & 26.7 & 31.0 & 13.8 & 13.3 & 20.0 & 66.7 & 23.3 & 43.3 \\
\hline HDL cholesterol & & & \multicolumn{3}{|c|}{$P=.053^{*}$} & \multicolumn{2}{|c|}{$P=.034 *$} & & & & & & & \\
\hline$<1 \mathrm{mmol} / 1$ & 19 & 71.4 & 28.6 & 22.2 & 66.7 & 62.2 & 24.3 & 32.4 & 77.8 & 0.0 & 66.7 & 66.7 & 35.1 & 44.4 \\
\hline$>1 \mathrm{mmol} / 1$ & 81 & 51.4 & 40.0 & 65.7 & 31.4 & 33.3 & 11.1 & 22.2 & 54.1 & 13.5 & 70.3 & 54.1 & 11.1 & 43.2 \\
\hline LDL cholesterol & \multicolumn{14}{|c|}{$p=.009^{*}$} \\
\hline$<3 \mathrm{mmol} / \mathrm{l}$ & 38 & 26.7 & 66.7 & 62.5 & 37.7 & 47.1 & 29.4 & 23.5 & 5.9 & 5.9 & 17.6 & 58.8 & 29.4 & 47.1 \\
\hline$>3 \mathrm{mmol} / \mathrm{l}$ & 62 & 70.4 & 22.2 & 53.6 & 29.3 & 62.1 & 17.2 & 34.5 & 13.8 & 17.2 & 17.2 & 55.2 & 31.0 & 41.4 \\
\hline $\begin{array}{l}\text { Waist } \\
\text { circumference }\end{array}$ & \multicolumn{14}{|c|}{$p=.026^{*}$} \\
\hline $\begin{array}{l}\text { Men } \\
<94 \mathrm{~cm}\end{array}$ & 7 & 25.0 & 50.0 & 75.0 & 25.0 & 50.0 & 0.0 & 0.0 & 25.0 & 50.0 & 0.0 & 25.0 & 25.0 & 75.0 \\
\hline$>95 \mathrm{~cm}$ & 36 & 66.7 & 33.3 & 52.9 & 47.1 & 61.1 & 16.7 & 29.4 & 5.9 & 11.1 & 16.7 & 66.7 & 16.7 & 61.1 \\
\hline $\begin{array}{l}\text { Women } \\
<80 \mathrm{~cm}\end{array}$ & 8 & 75.0 & 25.0 & 25.0 & 75.0 & 75.0 & 0.0 & 25.0 & 0.0 & 0.0 & 0.0 & 75.0 & 100 & 0.0 \\
\hline$>81 \mathrm{~cm}$ & 49 & 52.0 & 40.0 & 64.0 & 28.0 & 46.2 & 11.0 & 42.3 & 15.4 & 11.3 & 23.1 & 46.2 & 23.1 & 30.8 \\
\hline
\end{tabular}

Published by Sciedu Press 
Table 8. Summary of self-assessment, self-reporting and objective measurements

\begin{tabular}{lll}
\hline Self-assessment & Self-reporting & Measurement \\
\hline Slightly overweight & & $\begin{array}{l}\text { waist circumference: men 106 cm, women } \\
95 \mathrm{~cm} \text { average BMI 30.4 }\end{array}$ \\
$\begin{array}{l}\text { 3-4 hours of everyday activities a week } \\
\text { Physical fitness }<2-3 \text { times a week for } 20\end{array}$ & $\begin{array}{l}\text { reported amount below recommendation } \\
\text { - } 60 \text { min }\end{array}$ & \\
$\begin{array}{l}\text { Vegetable intake below recommendation } \\
\text { Soft fat on bread and in cooking }\end{array}$ & $\begin{array}{l}\text { reported amount below recommendation } \\
\text { reported amount as recommended }\end{array}$ & \\
Fatty cheese and snacks & $\begin{array}{l}\text { hard fat intake exceeded } \\
\text { recommendation }\end{array}$ & total cholesterol level and LDL elevated \\
Vegetable intake and fibre content & of & \\
bread below recommendation & fibre intake below recommendation & total cholesterol level and LDL elevated \\
Cheese and cold cuts & salt intake exceeded recommendation & total cholesterol level and LDL elevated \\
\hline
\end{tabular}

Participants did not exercise enough, either when related to their health or when compared to the recommendations ${ }^{[19]}$. Regular and sufficient physical activity helps to decrease waist circumference and to prevent chronic diseases ${ }^{[20,21]}$. There was a discrepancy between self-assessed and self-reported everyday physical activity. Participants assessed that they exercised regularly in the form of commuting, daily life and gardening but, according to the diaries, the minimum recommendation for everyday physical activity was not met. By increasing daily exercise, the risk of cardiovascular diseases decreases ${ }^{[18]}$ and even small amount of light exercise during the working day has a positive effect on cardiovascular health ${ }^{[22]}$. However, the benefit from exercise increases significantly when both the intensity and amount of exercise are increased ${ }^{[23]}$.

With regard to vegetable use, self-assessed lifestyle parameters and food diary records matched the actual consumption. However, participants ate fewer vegetables in total than recommended. Daily consumption of fruit and vegetables has a positive effect on cardiovascular health ${ }^{[24]}$.

Based on the food diary analysis, total fat intake was at the recommended level. Over half of the participants assessed that they used monounsaturated fat on bread and in cooking. This result agreed with the food diaries, and the recommendation for soft fat usage was also followed. However, the intake of saturated fat exceeded the recommended levels ${ }^{[15]}$. According to the self-assessment, the sources of hard fat were cheese and fatty snacks. It is important to take into account the relationship between unsaturated and saturated fat in the daily diet. Also with regards to fibre intake, the participants' own assessment and food diary records agreed with the actual intake levels; however, most participants did not receive enough fibre.

A link between participants' cholesterol level and diet was observed. Saturated fat in food increases total cholesterol level in addition to $\mathrm{LDL}^{[25,26]}$ which was also observed in the participants blood test results. Fibre intake has also been shown to reflect cholesterol level; that is, fibre decreases LDL cholesterol in blood ${ }^{[25,26]}$. The participants' fibre intake was low which was linked to the increased cholesterol level. Blood cholesterol reacts quickly to changes in diet ${ }^{[26]}$.

The participants' blood pressure was satisfactory although their salt intake significantly exceeded the recommended level. Though diet as a whole forms the basis for health and weight control, the quality of fat, a sufficient quantity of vegetables and fibre, and moderate salt use are key preventatives of cardiovascular diseases ${ }^{[26-28]}$.

Participants realised that physical activity and diet affect well-being. Through minor but permanent changes in diet and physical activity, health and well-being can gradually be improved ${ }^{[20,29]}$. Moderate alcohol consumption and no smoking are absolute preconditions for good health. Although all the health parameter measurement results did not meet the recommendations, and though improvement is required with regards to physical activity and diet, participants assessed their health to be good or quite good. 
In this study, health care professionals carried out all measurements. Consequently, these measurement results are more reliable than if participants had taken them themselves, see Spencer ${ }^{[30]}$. One challenge in lifestyle questionnaire studies is the possibility for over-reporting or under-reporting, either consciously or subconsciously. However, self-assessment information is very important because it represents people's own perspective of their lifestyle. It is known that personal perspective underlies the choices that people make.

Assessment of everyday physical activity is challenging. Exercise is often regarded as being sufficient or even exceeding recommendations (over-reporting) as witnessed in this study. It has been found that the obese tend to over-report physical activity ${ }^{[31]}$ which was also the finding in this research. Those participants whose health parameter measurement results exceeded recommendations believed that they exercised more than they actually did (over-reporting). In addition, they assessed that their diet followed recommendations more than those whose measurement results were within the normal range.

As people become more aware of what affects health and well-being, lifestyle and dietary studies are bound to encounter under-reporting issues. Many feel guilty of their eating habits and, therefore, participants may embellish results either consciously or subconsciously ${ }^{[32]}$. Moreover, the assessment of one's own lifestyle may be affected by general opinion, such as preferred health behaviour or appearance, or what is generally socially acceptable as, for example, in the case of smoking and alcohol consumption ${ }^{[7]}$.

In some previous studies, it has been found that women and the overweight ${ }^{[3-35]}$, in addition to less well-educated people ${ }^{[9,34]}$, tend to under-report their eating. However, Novotny ${ }^{[36]}$ did not find significant differences between men and women. In this study, the purpose was not to compare results between sexes but rather to form a summarized view of how self-assessment and self-reporting agree with measurement results.

Unreliable reporters have been found to under-report their consumption of unhealthy food selectively ${ }^{[9,37]}$. In this research, the participants' daily energy intake ${ }^{[15]}$ was low which contradicts their significant overweight. This may be an indication of dietary under-reporting. Under-reporting may have a significant consequence if one under-reports in, for example, a diabetes risk test. Consequently, the risk may remain unidentified and the person with the underlying risk will be left without the required care.

Cognitive processes such as comprehension, memory retrieval, decision-making and response generation affect selfassessment and self-reporting, and potential errors affecting research validity may occur in all of these processes ${ }^{[7]}$. It is easier to recall and evaluate concrete items such as daily vegetable intake. This was also found in this research when comparing, for example, the "I don't know" answers between the amount of vegetables and the amount of fibre consumed. In order for the participant to be specific about answering the lifestyle questionnaire (e.g. what kind of fat is used on bread), one must be interested and aware of daily choices by, for example, reading grocery packaging. Interpretation of the assessment scale (e.g. how one defines "quite good") affects participants' answers, something found by Shephard ${ }^{[10]}$ in his study. Those with weaker cognitive skills have been found to under-report their eating ${ }^{[9]}$. Nationality has also been found to affect assessment answers ${ }^{[29]}$.

Although self-assessment and self-reporting both depend on cognitive and situational factors, validity differs between the different measures ${ }^{[22]}$, and cannot be predicted or evaluated unambiguously.

A detailed assessment of physical activity using questionnaires is problematic due to the lack of a clear definition of particular types of exercise ${ }^{[10]}$. It is challenging to classify and differentiate between different types of activities, understand and internalise different terms as well as to define the length and intensity of certain types of physical activity ${ }^{[7,10]}$. In this study, participants separately assessed everyday physical activity and physical fitness. They were provided with specific definitions and criteria as to how to fill in the lifestyle questionnaire and exercise diary. Despite the 
clear guidance, it was found that it was easier to assess and report physical fitness than everyday physical activity. Such diaries form a good basis for investigating the internalisation of physical activity terminology.

At present, technology provides more objective means for measuring physical activity. For example, a pedometer, a heart rate monitor and an accelerometer enable direct measurement of inactivity and energy consumption ${ }^{[38-40]}$. Food diary information, on the other hand, cannot be obtained in the same way as such, but new instruments for evaluating energy consumption have been developed. Single nutrient intake and effect can be investigated by using biomarkers ${ }^{[41]}$.

In this research, the study population was rather small. Due to the voluntary nature of the study and lack of commitment reduced the number of participants. With regard to method, another issue to take into account in self-assessment studies is the Hawthorne effect, which refers to the effect of being under observation ${ }^{[42]}$. These issues may affect results interpretation and generalisation in this study as well. Chiuve ${ }^{[43]}$ has found that, although errors in reporting lifestyle are inevitable, self-assessment and self-reporting provide such unique information and understanding which cannot be gained otherwise ${ }^{[44]}$.

However, this type of research provides important input for health care policy makers when prioritising preventative health care actions to improve national health ${ }^{[45]}$. In this study, asymptomatic 40 -year-olds from a particular region in Finland were selected as participants. They represented a special research target group due to their expected disease heredity, age and life situation. Cardiovascular diseases have been associated with family history ${ }^{[46]}$ and thereby, the region provided interesting research environment in this study. These types of studies, which are conducted on asymptomatic participants, contribute to the identification of people with risk factors and the early prevention of cardiovascular diseases ${ }^{[4]}$.

\section{Conclusions}

The strengths of this study were the multifaceted data collection approach, which provided a versatile view of studying lifestyle, and the special nature of engaging voluntary participants to screenings and the reporting process. Participants' own assessment of their lifestyle was not fully in line with either the reported lifestyle or health parameter measurement results. Consequently, in order to form as objective view as possible of a person's lifestyle, self-assessment and selfreporting as a method may not be sufficient.

Although self-assessment as a method always incorporates some degree of error, it is a valuable research method when studying lifestyle. In the future, improved technology for measurements and observations can be utilised together with self-assessment and self-reporting in order to provide objective information about lifestyle and the means for implementing lifestyle changes and counselling interventions.

\section{References}

[1] Global Strategy on diet, physical activity and health WHO www.who.int/dietphysicalactivity/diet/en/index.html

[2] White Paper A Strategy on Nutrition, Overweight and Obesity - related health issues 2007. Available from: www.ec.europa.eu/health/ph_determinants/life_style/nutrition_polic_en.htm

[3] Health Strategy White Paper 2007. Available from: ec.europa.eu/healtheu/health_in_the_eu/policies/index_fl.htm

[4] Quality Recommendation for Health Promotion. Publications of the Ministry of Social Affairs and Health, Finland. Helsinki 2006: 19.

[5] Eriksson M.K., Westborg C-L., Eliasson M.C.E. A randomized trial of lifestyle intervention in primary healthcare for the modification of cardiovascular risk factors. Scandinavian Journal of Public Health. 2006; 34: 453-461. PMid:16990155 http://dx.doi.org/10.1080/14034940500489826

[6] Maruthur N.M., Wang N.Y., Appel L. J. Lifestyle Interventions Reduce Coronary Heart Disease Risk: results Form the Premier Trial. Circulation. 2009; 119: 2026-2031. PMid:19349322 http://dx.doi.org/10.1161/CIRCULATIONAHA.108.809491 
[7] Brener N D., Billy J O G., Grady W R. Assessment of Factors Affecting the Validity of Self- Reported Health-Risk Behavior Among Adolescents: Evidence From the Scientific Literature. Journal of Adolescent Health. 2003; 33: 436-457. http://dx.doi.org/10.1016/S1054-139X(03)00052-1

[8] Helakorpi S., Holstila A-L., Virtanen S., Uutela A. Health Behaviour and Health among the Finnish Adult Population, Spring 2011. Publications of the National Public Health Institute, 45/2012

[9] Krebs-Smith SM., Graubard BI., Kahle LL., Subar AF., Cleveland LE., Ballard-Barbash R. Low energy reporters vs others: a comparison of reported food. European journal of clinical nutrition. 2000; 54: 281-287. PMid:10745278 http://dx.doi.org/10.1038/sj.ejen.1600936

[10] Shephard R.J. Limits to the measurement of habitual physical activity by questionnaires. British Journal of Sports Medicine. 2003; 37: 197-206. http://dx.doi.org/10.1136/bjsm.37.3.197

[11] Wolf A.M., Siadaty M.S., Crowther J.Q., Nadler J.L., Wagner D.L., Cavalier S.L. et al. Impact of lifestyle intervention on lost productivity and disability: improving control with activity and nutrition. Journal of Occupational \& Environmental Medicine. 2009; 2: 139-145. PMid:19209034 http://dx.doi.org/10.1097/JOM.0b013e3181965db5

[12] Lindström J., Tuomilehto J. The Diabetes Risk Score. A practical tool to predict type 2 diabetes risk. Diabetes Care. 2003; 29: 725-731. http://dx.doi.org/10.2337/diacare.26.3.725

[13] Saaristo T., Peltonen M., Lindström J., Saarikoski L., Sundvall J., Eriksson J.G., Tuomilehto J. Cross- sectional evaluation of the Finnish Diabetes Risk Score: a tool to identify undetected type 2 diabetes, abnormal glucose tolerance and metabolic syndrome. Diabetes and vascular disease research. 2005; 2(2): 67-72. PMid:16305061 http://dx.doi.org/10.3132/dvdr.2005.011

[14] Nordic Nutrition Recommendations 2013. http://www.norden.org/en/theme/nordic-nutrition-recommendation.

[15] Finnish nutrition recommendations 2005. National Nutrition Council. Available from: http://www.ravitsemusneuvottelukunta.fi/portal/en/nutrition+recommendations/

[16] Wijndaele K., Healy G.N., Dunstan D.W., Barnett A.G., Salmon J., Shaw J.E, Zimmet P.Z., Owen N. Increased cardiometabolic risk is associated with increased TV viewing time. Medicine and Science in Sports and Exercise. 2010: 42; $1511-1518$. PMid:20139784 http://dx.doi.org/10.1249/MSS.0b013e3181d322ac

[17] Thorp A., Healy G., Owen N., Salmon J., Ball K., Shaw J., Zimmer P., Dunstan D. Deleterious Associations of Sitting Time and Television Viewing Time with Cardiometabolic Risk Biomarkers. Diabetes Care. 2010; 3: 327-334. PMid:19918003 http://dx.doi.org/10.2337/dc09-0493

[18] Jensen M.K, Chiuve S.E., Rimm E.B., Dethlefsen C., Tjønneland A., Joensen A.M., Overvad K. Obesity, Behavioral Lifestyle Factors, and Risk OF Coronary Events. Cieculation. 2008; 117: 3062-3069. PMid:18541738 http://dx.doi.org/10.1161/CIRCULATIONAHA.107.759951

[19] Haskell W.L., Lee I-M., Pate R.R., Powell K.E., Blair S.N., Franklin B.A. et al. Physical Activity and Public Health: Update Recommendation for Adults from the American College of Sports Medicine and the American Heart Association. Medicine \& Science in Sports \& Exercise. 2007; 39: 423-1434. PMid:17762377 http://dx.doi.org/10.1249/mss.0b013e3180616b27

[20] Ekelund U., Besson H., Luan J., May AM., Sharp SJ., Brage S., et al. Physical activity and gain in abdominal adiposity and body weight: perspective cohort study in 288,498 men and women. The American Journal of Clinical Nutrtion. 2011; 93: 826-35. PMid:21346093 http://dx.doi.org/10.3945/ajcn.110.006593

[21] Arsenault B., Rana J., Lemieux I., Després J., Kastelein .J, Boekholdt S., Wareham N., Khaw K. Physical inactivity, abdominal obesity and risk of coronary heart disease in apparently healthy men and women. International Journal of Obesity. 2010: 34; 340-347. PMid:19918249 http://dx.doi.org/10.1038/ijo.2009.229

[22] Held C., Iqbal R., Lear S.A., Rosengren A., Islam S., Mathew J., Yusuf S. Physical activity levels, ownership of goods promoting sedentary behaviour and risk of myocardial infarction: results of the interheart study. European Heart Journal 2012; 33: 452-466. PMid:22238330 http://dx.doi.org/10.1093/eurheartj/ehr432

[23] Samitz G., Egger M., Zwahlen M. Domains of physical activity and all-cause mortality: systematic review and dose-response meta-analysis of cohort studies. International Journal Epidemiology. 2011; 40: 1382-1400. PMid:22039197 http://dx.doi.org/10.1093/ije/dyr112

[24] Uusitupa M., Hermansen K., Savolainen M.J., Schwab U., Kolehmainen M., Brader L. et al. Effects of an isocaloric healthy Nordic diet on insulin sensitivity, lipid profile and inflammation markers in metabolic syndrome - a randomized study (SYSDIET). Journal of Internal Medicine. 2013; 274: 52-66. PMid:23398528 http://dx.doi.org/10.1111/joim.12044

[25] McCall D.O., McGartland C.P., McKinley M.C., Patterson C.C., Sharpe P., McCance D.R. et al. Dietary Intake of Fruits and Vegetables Improves Microvascular Function in Hypertensive Subjects in a Dose-Dependent Manner. Circulation. 2009; 119: 2153-2160. PMid:19364976 http://dx.doi.org/10.1161/CIRCULATIONAHA.108.831297

[26] Chen S.T., Maruthur N.M., Appel L.J. The Effect of Dietary Patterns on Estimated Coronary Heart Disease Risk: Results From the Dietary Approaches to Stop Hypertension (DASH) Trial. Circulation Cardiovascular Quality and Outcomes. 2010 ; 3: 484-489. PMid:20807884 http://dx.doi.org/10.1161/CIRCOUTCOMES.109.930685 
[27] Reiner Z., Catapano A.L., De Backer G., Graham I., Taskinen M-R., Wiklund O., et al. ESC/EAS Guidelines for the management of dyslipidemias. European Heart Journal. 2011; 32: 1769-1818. PMid:21712404

[28] Dehghan M., Mente A., Teo K.K.,Sleight P., Dugernais G., Avezum A., et al. Relationship Between Healthy Diet and Risk of cardiovascular Disease Among Patients on Drug Therapies for Secondary Prevention: A Prospective Cohort Study of 310546 Hog-Risk Individuals From 40 Countries. Circulation. 2012; 126: 2705-2712. PMid:23212996 http://dx.doi.org/10.1161/CIRCULATIONAHA.112.103234

[29] Estruch R., Ros E., Salas-Salvado J. Primary Prevention of Cardiovascular Disease with a Mediterranean Diet. The New England Journal of Medicine. 2013; 4: 1279-1290. PMid:23432189 http://dx.doi.org/10.1056/NEJMoa1200303

[30] Mozaffarian D., HaoT., Eric B.,Rimm E.B.,Willett W.C.,Frank B., Hu F.B . Changes in Diet and Lifestyle and Long-Term Weight Gain in Women and Men. New England Journal of Medicine. 2011; 364: 2392-240. PMid:21696306 http://dx.doi.org/10.1056/NEJMoa1014296

[31] Spencer E.A., Appleby P.N., Davey G.K., Key T.J. Validity of self-reported height and weight in 4808EPIC-Oxford participants. Public Health Nutrition. 2002; 5: 561-656. PMid:12186665 http://dx.doi.org/10.1079/PHN2001322

[32] Schelling S., Munsch S., Meyer A.H., Newark P., Biedert E.M. Increasing the motivation for Physical Activity in obese patients. International Journal of Eating Disorders. 2009; 42: 130-138. PMid:18951454 http://dx.doi.org/10.1002/eat.20595

[33] Paturi M., Tapanainen H., Reinivuo H., Pietinen P, eds. Finravinto 2007 - tutkimus - The National FINDIET 2007 Survey Publications of the National Public Health Institute. B23/2008.

[34] Jürges H., True Health vs. Response Styles: Exploring Cross-country Differences in Self-reported Health, DIWDiskussionspapiere. 2006, No. 588.

[35] Bailey R.L., Mitchell D.C., Miller C., Smiciklas-Wright H. Assessing the effect of underreporting energy intake on dietary patterns and weight status. Journal of the American dietetic Association. 2007; 107: 64-71. PMid:17197273 http://dx.doi.org/10.1016/j.jada.2006.10.009

[36] Maurer J., Taren D.L., Teixeira P.J., Thomson C.A., Lohman T.G., Going S.B., Houtkooper L.B. The psychosocial and behavioural characteristics related to energy misreporting. Nutr Rev. 2006; 64: 53-66. PMid:16536182 http://dx.doi.org/10.1111/j.1753-4887.2006.tb00188.x

[37] Novotny J.A., Rumpler W.V., Riddick H., Hebert J.R., Rohdes D., Judd J.T., et al. Personality characteristics as predictors of underreporting of energy intake on 24-hour dietary recall interviews. Journal American Dietetic Association. 2003; 103: 1146-1151. http://dx.doi.org/10.1016/S0002-8223(03)00975-1

[38] Scagliusi F.B., Polacow V.O., Artioli G. G., Benatti F. B. Selective underreporting of energy intake in Women: magnitude, determinants, and effect of training. Journal of the American Dietetic Association. 2003; 103: 1306-1313. http://dx.doi.org/10.1016/S0002-8223(03)01074-5

[39] Hart T.L,. Ainsworth B.E,. Tudor-Locke C. Objective and Subjective Measures if Sedentary Behaviour and Physical Activity. The American College of Sports Medicine. 2001; 43: 449-456.

[40] Westerterp K.R. Assessment of physical activity: a critical appraisal. European Journal of Applien Physiology. 2009 ; $105: 823-828$. PMid:19205725 http://dx.doi.org/10.1007/s00421-009-1000-2

[41] Matthews C., Hagströmer M., Pober DM., Bowles H. Best practices for using physical activity monitors in population - based research. Medicine and Science in Sports and Exercise 2012; 44: S68-S76. PMid:22157777 http://dx.doi.org/10.1249/MSS.0b013e3182399e5b

[42] Subar A F., Kipnis V., Troiano R P., Midthune D., Schoeller D A., Bingham s., er al. Using intake biomarkers to evaluate the extent of dietary misreporting in a large sample of adults: the OPEN study. American Journal of Epidemiology. 2003; 158 : 1-13. PMid:12835280 http://dx.doi.org/10.1093/aje/kwg092

[43] Polit D.F., Beck C.T. Nursing Research: Appraising Evidence for Nursing Practice. Philadelphia: Wolter Kluwer Health / Lippincot Williams \& Wilkins. 2010: 222-257.

[44] Chiuve S.E., Mc Cullough M.L., Sacks F.M., Rimm E.B. Healthy Lifestyle Factors in the Primary prevention of Coronary Heart Disease Among Men. Circulation. 2006; 114: 160-167. PMid:16818808 http://dx.doi.org/10.1161/CIRCULATIONAHA.106.621417

[45] Smedt D.D., Clays E., Annemans L., Boudrez H., De Sutter J. The association between self- reported lifestyle changes and health-related quality of life in coronary patients: the EUROASPIRE III survey. European Journal of Preventive Cardiology. 2013 Jan 10.

[46] Bachmann J.M., Willis B.L., Ayers C.R., Khera A., Berry J.D. Association Between Family History and Coronary Heart Disease Death Across Long-Term Follow-Up in Men. Circulation. 2012; 125: 3092-3098. PMid:22623718 http://dx.doi.org/10.1161/CIRCULATIONAHA.111.065490

[47] Ferro A., Cinquetti S., Moro A., Siddu A., Trimarchi A., Penon M.G., Pavan P., Camillotto R., Rossetto L., Volpe V., Zevrain S., Brusaferro S. Preventing cardiovascular diseases through a screening modelling applicable to wide population groups: results from the first phase of the project. Epidemiologia e prevenzione. 2014; 38: 38-45. PMid:24736960 